\title{
MANAGEMENT OF VENOUS THROMBOEMBOLIC DISORDERS
}

\author{
Diana S. Purwanto
}

\author{
Bagian Biokimia Fakultas Kedokteran Universitas Sam Ratulangi Manado \\ Email: shintapurwanto@yahoo.co.id
}

\begin{abstract}
Abstrak: Tromboemboli vena (VTE) mengacu pada semua bentuk trombosis patologik yang terjadi dalam sirkulasi vena, dimana paling umum yaitu trombosis vena dalam (DVT) pada ekstremitas bawah. Manifestasi VTE yang paling mengancam nyawa ialah embolisasi trombi vena dalam ke sirkulasi paru, yang disebut emboli paru (PE). Terdapat banyak faktor baik yang diturunkan atau didapat, bisa menyebabkan VTE karena faktor-faktor tersebut mempengaruhi stasis vena, kerusakan pembuluh dan hiperkoagulabilitas, yang berperan sebagai pemicu peristiwa trombotik. Sebuah kombinasi dari tes D-dimer dan probabilitas klinis diperkenalkan oleh Wells sebagai langkah pertama dalam diagnosis. Agen antikoagulan, biasanya unfractionated heparin (UFH) atau low molecular weight heparin (LMWH), harus diberikan untuk menghindari pembentukan bekuan lebih lanjut ketika gangguan VTE dikonfirmasi. Pada saat efek antitrombotik yang memadai dicapai dengan heparin, antikoagulan oral seperti warfarin digunakan untuk mengurangi kemungkinan VTE berulang.
\end{abstract}

Kata kunci: Tromboemboli vena, DVT, PE, D-dimer, antikoagulan.

\begin{abstract}
Venous thromboembolism (VTE) refers to all forms of pathological thrombosis occurring on the venous side of circulation, the most common of which is deep venous thrombosis (DVT) of the lower extremities. The most life-threatening manifestation of VTE is embolization of venous thrombi to the pulmonary circulation, called pulmonary embolism (PE). Many factors, either inherited or acquired, can cause VTE, since these factors influence the venous stasis, vessel damage, and hypercoagulability, as the trigger of a thrombotic event. A combination of a D-dimer assay and clinical probability as a first step in diagnostic work-up was introduced by Wells et al. An initial management of anticoagulant agents usually unfractionated heparin (UFH) or low molecular weight heparin (LMWH), should be administered to avoid further clot formation when VTE disorder is confirmed. At some point an adequate antithrombotic effect is achieved with heparin, or an oral anticoagulant such as Warfarin. These can be started to reduce the probability of recurrent VTE.
\end{abstract}

Keywords: Venous thromboembolism, DVT, PE, D-dimer, anticoagulant.

Venous thromboembolism (VTE), which is comprised of deep vein thrombosis (DVT) and pulmonary embolism $(\mathrm{PE})$, is a major health challenge. Deep vein thrombosis (DVT) is a condition in which thrombosis takes place in the deep vein system, mostly of the lower limbs, either proximal (from and above the popliteal vein), or distal (under the popliteal veins). Pulmonary embolism (PE) occurs when a blood clot is broken off and this fragment, called embolus, is carried 
with the flow of blood and then lodged in the arterial pulmonary vasculature. ${ }^{1,2}$

The incidence of venous thromboembolism including deep vein thrombosis (DVT), and pulmonary embolism (PE), in Western populations is known to be 71-117 cases per 100,000 each year, and that rises exponentially from $<5$ cases per 100,000 persons under 15 years old to nearly 500 cases per 100,000 persons at age $>80$ years. ${ }^{3}$ The incidence of VTE in the United States, including recurrent, fatal, and nonfatal is above 900,000 every year. ${ }^{4}$ The direct medical costs for the treatment of nonfatal VTE is thought to be between 5.8 to 7.8 billion dollars (based on 2004 provider payments). ${ }^{5}$

Many factors, either inherited or acquired, can cause VTE, since these factors influence the venous stasis, vessel damage and hypercoagulability which is the trigger of the thrombotic event. Examples of inherited predisposition to VTE are defects in the natural inhibitors of coagulation (deficiencies of antithrombin, protein $\mathrm{C}$, and protein $\mathrm{S}$ ); factor $\mathrm{V}$ Leiden mutation that causes the ineffectiveness of activated protein $\mathrm{C}$; and mutation of the prothrombin gene (G20210A) which produces an excess of prothrombin formation. Conversely, the acquired features are malignancy, major trauma, paralysis, prolonged immobility, lower limb injuries, obesity, age over 40 years, pregnancy, or estrogen therapy. ${ }^{6}$

This review focuses primarily on the diagnosis, which includes clinical assessment, laboratory investigation, and radiological diagnosis, as well as provides an overview of the treatment of VTE.

\section{DIAGNOSIS OF VENOUS THROMBO- EMBOLISM}

\section{Clinical Diagnosis}

Clinical features of DVT include pain, redness, and oedema of affected extremity are not specific, as these can be found in other diseases, such as cellulitis, muscle strain, Baker popliteal cyst, external venous compression, superficial thrombophlebitis, and post-thrombotic syndrome. Similarly, $\mathrm{PE}$ signs and symptoms are insensitive, as PE can exist in one of three presentations: dyspnea with or without pleuritic pain, isolated dyspnea, or syncope. ${ }^{2}$

However, these signs and symptoms can be applied in Wells clinical prediction rule for DVT and PE to classify patients into a high, intermediate, or low clinical probability of having the disease (Table 1 and 2). Moreover, this classification is effective in guiding the interpretation of further diagnostic tests. ${ }^{2,7}$

Table 1. Description of the Wells Score for patients with clinically suspected deep vein thrombosis (DVT) ${ }^{2}$

\begin{tabular}{lc}
\hline \multicolumn{1}{c}{ Wells clinical prediction score } & Points \\
\hline Cancer & +1 \\
Paralysis or recent immobilization & +1 \\
Bedridden >3d, or surgery/trauma <4wk & +1 \\
Pain on palpation of the deep veins & +1 \\
Oedema of thigh and calf & +1 \\
Pitting oedema (symptomatic side only) & +1 \\
Dilated superficial veins (symptomatic side only) & +1 \\
Alternative diagnosis at least as likely as DVT & -2 \\
\hline Clinical probability : & $\leq 0$ \\
Low & $1-2$ \\
Intermediate & $\geq 3$ \\
High & \\
\hline
\end{tabular}


Table 2. Description of two externally validated scores in patients with clinically suspected $\mathrm{PE}^{2}$

\begin{tabular}{lclc}
\hline Geneva prediction score for PE & Points & Wells clinical prediction score for PE & Points \\
\hline Previous PE or DVT & +2 & Previous PE or DVT & +1.5 \\
Heart rate $>100 / \mathrm{min}$ & +1 & Heart rate $>100 /$ min & +1.5 \\
Recent surgery & +3 & Recent surgery or immobilization & +1.5 \\
Age : & & Clinical signs of DVT & +3 \\
$60-79$ & +1 & Alternative diagnosis less likely than PE & +3 \\
$\geq 80 \mathrm{yr}$ & +2 & Hemoptysis & +1 \\
$\mathrm{PaCO}_{2}$ & & Cancer & +1 \\
$<4.8 \mathrm{kPa}(36 \mathrm{mmHg})$ & +2 & & \\
$4.8-5.19 \mathrm{kPa}(36-38.9 \mathrm{~mm} \mathrm{Hg})$ & +1 & & \\
$\mathrm{PaO}$ & & & \\
$<6.5 \mathrm{kPa}(48.7 \mathrm{mmHg})$ & +4 & & \\
$6.5-7.99 \mathrm{kPa}(48.7-59.9 \mathrm{mmHg})$ & +3 & & \\
$8-9.49 \mathrm{kPa}(60-71.2 \mathrm{mmHg})$ & +2 & & \\
$9.5-10.99 \mathrm{kPa}(71.3-82.4 \mathrm{mmHg})$ & +1 & & \\
Atelectasis & +1 & & $2-6$ \\
Elevated hemidiaphragm & +1 & & $\geq 7$ \\
\hline Clinical probability & & Clinical probability & \\
Low & $0-4$ & Low & \\
Intermediate & $5-8$ & Intermediate & \\
High & $\geq 9$ & High & \\
\hline
\end{tabular}

\section{Laboratory Testing}

A D-dimer test measures cross-linked fibrin degradation products broken down by plasmin, and the levels are usually elevated in acute VTE, showing continuing activation of fibrinolysis. However, a positive D-dimer test on its own is not specific, because it can be found in various disorders that the activation of coagulation and consequent fibrinolysis happens, for example cancer or post surgery. Therefore, to exclude the diagnosis of VTE, the normal result of a high sensitive D-dimer test $(>98 \%$, as it has a high negative predictive value /NPV), together with a low clinical prediction score or another high NPV objective test are needed. ${ }^{5}$ The Ddimer test, by using a quantitative enzymelinked immunoassay (ELISA) or some automated turbidimetric assays, has been verified to be very sensitive $(>98 \%){ }^{2}$ A management study of 6837 consecutive outpatients suspected of having VTE showed that a combination of a D-dimer result and clinical prediction assessment permits fast and secure elimination of a VTE diagnosis as much as $30-50 \% .^{8}$

\section{Diagnostic Imaging}

\section{Contrast venography}

It is the first-line technique for diagnosing DVT because it can detect both proximal vein thrombosis and isolated calf vein thrombosis. ${ }^{5}$ Nevertheless, it has a limitation, such as the pain for the patients because it involves contrast dye injection, the risk of hypersensitivity or toxic reactions to contrast media, the requirement of technical expertise, and the expensive cost. In the condition of an impaired venous access, such as obesity or oedema, the test is not successfull for around $10 \%$ of patients. $^{7}$

\section{Venous Doppler ultrasonography}

This is a choice of method for evaluating DVT, because it is non-invasive, accurate for the detection of proximal vein thrombosis (sensitivity, specificity, and NPV are about 97\%, 94\% and 98\%, respectively) and widely available. ${ }^{9}$ The principle of DVT diagnostic is based on the inability to completely compress the vein lumen when applying pressure through the ultrasound probe. ${ }^{2,5}$ However, this assess- 
ment has restrictions, in which it cannot differentiate an old clot from a new clot, is less accurate to detect DVT in the pelvis or in the calf, and relies on the operator to perform accurate result. ${ }^{7}$

\section{Magnetic resonance imaging}

For evaluating thrombosis in the calf and pelvis or diagnosing DVT in asymptomatic and pregnant patients, the MRI emerges to be very accurate. This technique also can distinguish between an old and new thrombus. However, its limited availability, highly cost and operator dependent, are the reasons to use MRI as second-line diagnostic tool. ${ }^{7}$

\section{Pulmonary angiography}

Anatomic arterial vasculature of the lung and embolic load can be described and quantified accurately, however this test is invasive, expensive, risky and dependent on expert. ${ }^{2,6}$

\section{Ventilation-perfusion lung scanning}

Displays pulmonary perfusion defect through radioactive tracer, and is stated as normal, low, intermediate and high probability of embolus. However, perfusion defects are not specific, and low probability cannot exclude PE. ${ }^{7}$ Therefore, a combination with clinical assessment is helpful in diagnosis, since a moderate or high clinical predictive score together with high probability lung scan confirms PE diagnosis. ${ }^{6}$

\section{Helical (spiral) computerized tomography}

Visualize pulmonary arteries up to segmental level, with a sensitivity and specificity almost $90 \%$ in central pulmonary emboli. ${ }^{2,7}$ However, it is still difficult to detect emboli at the subsegmental (isolated) level, showing that specificity of this technique also relies on vascular level. Nevertheless, a thrombus scanned up to segmental level is a sufficient confirmation of PE. ${ }^{2}$

\section{Magnetic resonance pulmonary angio- graphy}

An advanced technology in evaluating suspected PE patients, however it is costly and not universally available. ${ }^{7}$

\section{TREATMENT OF VENOUS THROM- BOEMBOLISM}

When a patient is diagnosed with proximal DVT or uncomplicated PE, an immediate treatment of antithrombotic agent should be administered to prevent more clots occur, unless there are contraindications to anticoagulant, such as severe thrombocytopenia and active hemorrhage. ${ }^{10}$ In several decades, unfractionated heparin (UFH) has been used as the anticoagulant regime. UFH is a sulphated glycosaminoglycan that binds to antithrombin and subsequently potentiates the inhibiton of thrombin, activated factor $\mathrm{X}$ (factor $\mathrm{Xa}$ ) and activated factor IX (IXa). For this reason it then prolongs Activated Partial Thromboplastin Time (APTT) and Thrombin Clotting Time (TCT). ${ }^{11,12}$ UFH is administered firstly by a proper bolus dose $(5,000-10,000$ units), then continued with a weight-based intravenous to reach an APTT between 1.5-2.5 times control. ${ }^{10,12} \mathrm{In}$ spite of its effectiveness and low-cost, UFH has adverse effects, include bleeding, thrombocytopenia and osteoporosis. ${ }^{11}$

Over the last ten years, low molecular weight heparin (LMWH), which is formed by chemical depolymerization of UFH, has replaced UFH as the anticoagulant for the initial treatment of VTE. With its reduced size and charge compared to UFH, LMWH binding less to endothelium, macrophage, and heparin binding proteins, therefore improving bioavailability. ${ }^{10}$ Also, LMWH can be managed without hospital admission and given by subcutaneous route once a day. On the other hand, LMWH has disadvantages, in which the occurrence of thrombocytopenia (heparin induced thrombocytopenia) still present, and in patients with renal failure (Glomerular Filtration Rate <30-45 $\mathrm{mL} / \mathrm{min}$ ), anti-Xa levels should be monitored closely since the LMWH is excreted mainly by the renal route. $^{10}$

To prevent chronic VTE, an extended 
anticoagulation is needed after initial treatment with UFH or LMWH. Vitamin K antagonist, for example Warfarin in the Coumarin class, is widely used as a longterm anticoagulant. Warfarin is commenced on the same day as heparin, with a starting dose of $5 \mathrm{mg}$ daily via oral route. Because of its onset of time is delayed, an adequate antithrombotic effect of Warfarin is attained in 4-5 days overlap with heparin. Before heparin is stopped, an international normalized prothrombin time ratio should achieve 2.0 -3.0 for 24 hours. The length of oral anticoagulant medication depends on patient reliability and disease-related factors, including the presence of inherited risk factors and bleeding risk. ${ }^{11}$

In recent times, various new anticoagulants for the prevention and treatment of VTE have been developed, such as Fondaparinux and Ximelagatran. Fondaparinux is a synthetic analog of the antithrombinbinding pentasaccharide chain found in UFH and LMWH, which binds to factor $\mathrm{Xa}^{6}{ }^{6}$ Even though it should be used cautiously in patients with major renal failure or a high risk of bleeding, it shows no relationship to the development of HIT, thus reduce the high rate of morbidity and mortality. ${ }^{10}$

\section{CONCLUSION}

Venous thromboembolism disease can manifest in two conditions, DVT and PE. Because the clinical features of VTE are not specific, Wells clinical prediction rule for DVT and PE to is effective in guiding the interpretation of objective testing.

The gold standards for VTE diagnosis are contrast venography and pulmonary angiography, which based on clot visualization. However, the limitations of these tests, mainly related to the invasiveness and high risks for the patient, results in the application of other noninvasive tests, such as MRI which could be more expensive.

Once VTE disorder is confirmed, an initial management of anticoagulant agents usually UFH or LMWH should be administered to avoid further clot formation. When an adequate antithrombotic effect is achieved with heparin, oral anticoagulant such as Warfarin is started to reduce the probability of recurrent VTE.

\section{REFERENCES}

1. Fritsma GA, Marques MB. Thrombosis risk testing. In: Rodak BF, Fritsma GA, Doig K, editors. Hematology Clinical Principles and Applications (Third Edition). Missouri: Saunders Elsevier, 2007; p. 605-29.

2. Bounameaux H, Perrier A. Diagnosis of venous thromboembolism. In: Colman RW, Marder VJ, Clowes AW, George JN, Goldhaber SZ, editors. Hemostasis and Thrombosis, Basic Principles and Clinical Practise (Fifth Edition). Philadelphia: Lippincott Williams \& Wilkins, 2001; p. 1279-97.

3. Lee CH, Cheng CL, Lin LJ, Tsai LM, Yang YK. Epidemiology and predictors of short-term mortality in symptomatic venous thromboembolism: A nationwide population-based study. Circ J. 2011;75:1998-2004.

4. Heit JA. The Epidemiology of venous thromboembolism in the community. Arterioscler Thromb Vasc Biol. 2008;28:370-2.

5. Emadi A, Streiff M. Diagnosis and management of venous hromboembolism: an update a decade into the new millennium. Archives of Iranian Medicine. 2011;14 (5):341-51.

6. Linkins LA, Kearon C. Venous thromboembolism. In: O'Shaughnessy D, Makris M, Lilicrap D, editors. Practical Hemostasis and Thrombosis (First edition). Massachusetts: Blackwell Publishing Ltd, 2005; p. 101-13.

7. Ramzi DW, Leeper KV. DVT and pulmonary embolism: Part I. Diagnosis. American Family Physician. 2004; 69(12):2829-36.

8. Cate-Hoek AJ, Prins MH. Management studies using a combination of D-dimer test result and clinical Probability to rule uut venous thromboembolism: a systematic review. J Thromb Haemost. 2005;3:2464-70.

9. Ho WK, Hankey GJ, Lee CH, Eikelboom JW. Venous thromboembolism: diagnosis and management of deep 
venous thrombosis. MJA 2005; 182(9):476-81.

10. Marks PW. Treatment of venous thromboembolism. In: Colman RW, Marder VJ, Clowes AW, George JN, Goldhaber SZ, editors. Hemostasis and Thrombosis, Basic Principles and Clinical Practise (Fifth Edition). Philadelphia: Lippincott Williams \& Wilkins, 2001; p. 1307-16.
11. McRae SJ, Ginsberg JS. Initial treatment of venous thromboembolism. Circ J. 2004, 110:3-9.

12. Bick RL. Heparin and low molecular weight heparins. In: Bick RL, editor. Disorders of Thrombosis \& Hemostasis, Clinical and Laboratory Practice (Third Edition). Philadelphia: Lippincott Williams \& Wilkins, 2002; p. 359-77. 